\title{
High-throughput analysis of DNA repair in microplates towards identification of inhibitors
}

Hiroyuki Kamiya

\begin{abstract}
Environmental factors can inhibit DNA repair and cause indirect mutagenic actions. Here the author introduces a recent paper on a novel high-throughput system to analyze the various enzymatic activities involved in base excision repair. Such systems will facilitate the identification of compounds that suppressively affect DNA repair.
\end{abstract}

Keywords: DNA repair, Base excision repair, High-throughput analysis

DNA, RNA, and their precursors (nucleoside 5' -triphosphates) are continuously damaged by environmental and endogenous mutagens/carcinogens, such as alkylating reagents, ultraviolet light, and reactive oxygen species [1-5]. Organisms have developed countermeasures against the lesions, including DNA repair and nucleotide pool sanitization systems. In the case of DNA, unrepaired lesions induce genomic instability and contribute to carcinogenesis.

Environmental factors possibly play two roles in mutagenesis. One is the modification of DNA and $2^{\prime}$-deoxyribonucleotides as described, and the other is the inhibition of DNA repair and nucleotide pool sanitization. Assessing the effects of environmental factors and determining their mechanisms are important to understand the interactions between genes and the environment, and to regulate compounds that are toxic for genetic information.

The base excision repair (BER) system repairs various forms of relatively small base damage, as well as abasic sites and single strand breaks [6]. In the case of damaged base repair, a DNA glycosylase specific for the modified base first recognizes the lesion and cleaves the $\mathrm{N}$-glycosyl

Correspondence: hirokam@hiroshima-u.ac.jp

Graduate School of Biomedical and Health Sciences, Hiroshima University,

1-2-3 Kasumi, Minami-ku, Hiroshima 734-8553, Japan bond. Monofunctional DNA glycosylases leave an abasic site, and APE1 nicks the DNA strand bearing the abasic site. Bifunctional DNA glycosylase/lyases excise the $\mathrm{N}$-glycosyl bond and conduct the strand scission. The strand cleavage and removal of the sugar moiety result in gap formation. Gap-filling by DNA polymerase (pol) and the complete chemical bond formation by DNA ligase restore the original genetic information.

Recently, Healing et al. reported a novel highthroughput system to analyze the various enzymatic activities involved in BER [7]. The assay can monitor the activities at each step in microplates. An oligodeoxyribonucleotide complex is fixed to the surface of a microplate and used as the substrate in the assay (Fig. 1). The complex contains a single lesion (a damaged base, abasic site, gap, or nick) and is labeled with fluorescein at the 5 '-end. When uracil or alkyladnine DNA glycosylase removes its damaged base substrate, subsequent alkaline denaturation cleaves the DNA strand and separates the labeled and immobilized strands. Thus, the glycosylase activity can be measured by the disappearance of fluorescein from the well. AP endonuclease activity is also measurable by similar procedures. For the DNA pol (gap-filling) and ligase analyses, the fluorescein retained in the well indicates the activities (an excess amount of 


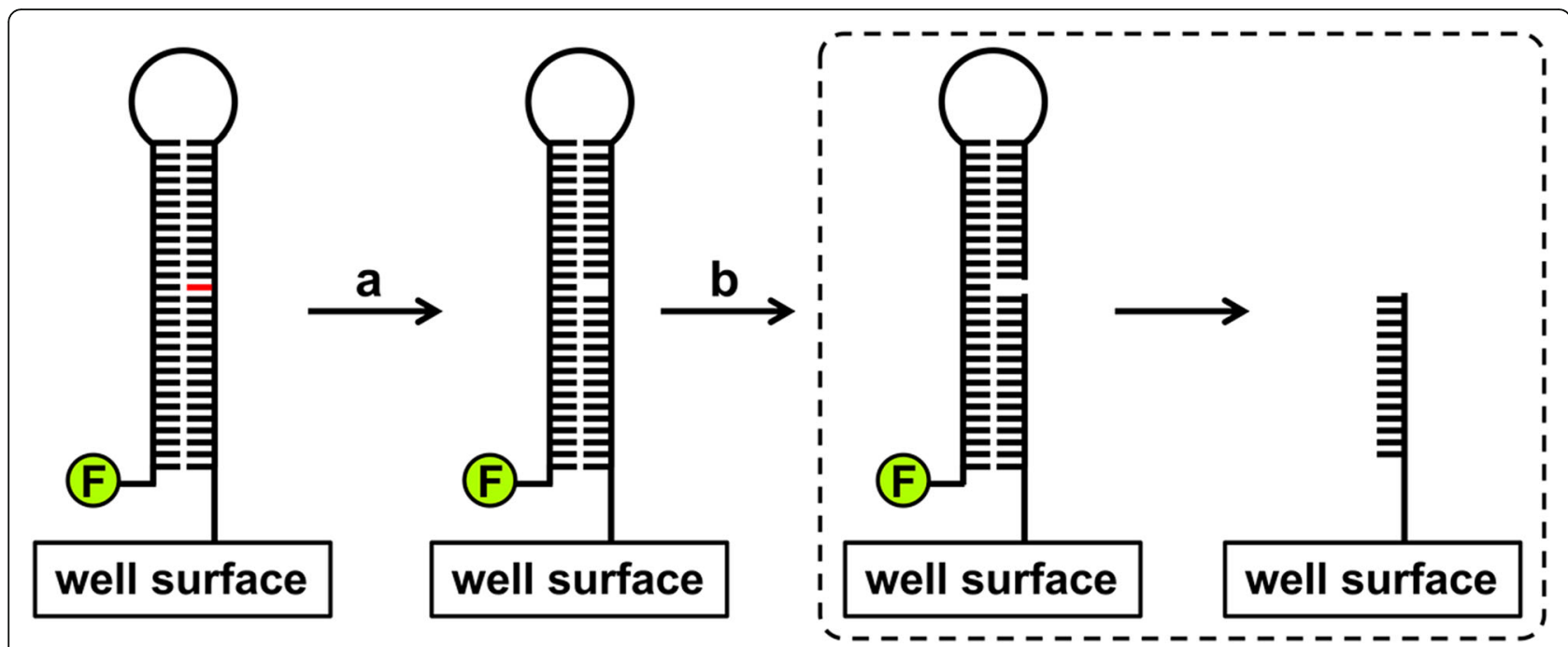

Fig. 1 The principle of the uracil DNA glycosylase assay. The substrate oligodeoxyribonucleotide is fixed to the surface of a microplate and bears a uracil base (shown in red) and fluorescein (shown as F) at the $5^{\prime}$-end. The action of glycosylase a forms an abasic site, and subsequent alkaline denaturation $\mathbf{b}$ induces the backbone cleavage and loss of fluorescein

T4 DNA ligase is added in the reaction mixture for the pol activity analysis).

This assay allows evaluations of the inhibitory (and stimulatory) influences of various compounds on the BER system. Many assay methods for BER enzymes have been proposed, and high-throughput screening systems have been used for the identification of DNA glycosylase inhibitors [8-10]. The new assay has a few distinct advantages over the previous assays: it can quantify each step of BER by employing basically the same system and also quantitate overall repair (from the abasic site) across multiple steps of BER. Similar assay systems could be prepared for the nucleotide excision repair. Highthroughput analyses using the systems would contribute to the discovery of the indirect mutagenic actions of environmental factors. In addition, analyses of the nuclear extracts from cells treated with compounds would lead to the identification of those that promote the degradation of DNA repair factors [11] and suppress their expression, as well as the inhibitors of each reaction. Conversely, these compounds are double-edged swords and possible therapeutic candidates that could enhance the efficacy of DNA-damaging anticancer drugs. The high-throughput systems will make significant contributions to human health through these two points of action.

\section{Abbreviations}

BER: base excision repair; pol: polymerase

\section{Acknowledgements}

The author thanks Drs. Hidehiko Kawai and Tetsuya Suzuki for reading the manuscript.
Author's contributions

HK wrote the manuscript. The author read and approved the final manuscript.

\section{Funding}

This work was supported in part by Japan Society for the Promotion of Science (JSPS) KAKENHI grant JP $19 H 04278$ (HK).

Availability of data and materials Not applicable.

Ethics approval and consent to participate Not applicable.

Consent for publication

Not applicable.

Competing interests

The author declares that he has no competing interests.

Received: 27 November 2019 Accepted: 5 February 2020

Published online: 09 March 2020

\section{References}

1. Margison GP, Santibáñez-Koref MF, Povey AC. Mechanisms of carcinogenicity/ chemotherapy by $0^{6}$-methylguanine. Mutagenesis. 2002;17:483-7.

2. Pfeifer GP, You Y-H, Besaratinia A. Mutations induced by ultraviolet light. Mutat Res Fundam Mol Mech Mutagen. 2005;571:19-31.

3. Kamiya H. Mutagenic potentials of damaged nucleic acids produced by reactive oxygen/nitrogen species: approaches using synthetic oligonucleotides and nucleotides: survey and summary. Nucleic Acids Res. 2003;31:517-31.

4. Suzuki T, Kamiya H. Mutations induced by 8-hydroxyguanine (8-oxo-7,8dihydroguanine), a representative oxidized base, in mammalian cells. Genes Environ. 2017:39:2.

5. Kawai K, Kasai H, Li Y-S, Kawasaki Y, Watanabe S, Ohta M, Honda T, Yamato $\mathrm{H}$. Measurement of 8-hydroxyguanine as an oxidative stress biomarker in saliva by HPLC-ECD. Genes Environ. 2018;40:5.

6. Barnes DE, Lindahl T. Repair and genetic consequences of endogenous DNA base damage in mammalian cells. Annu Rev Genet. 2004;38:445-76.

7. Healing E, Charlier CF, Meira LB, Elliott RM. A panel of colorimetric assays to measure enzymatic activity in the base excision DNA repair pathway. Nucleic Acids Res. 2019;47:e61. 
8. Lee CY, Kim H, Park KS, Park HG. Nucleic acid-based fluorescent methods for the determination of DNA repair enzyme activities: a review. Anal Chim Acta. 2019;1060:30-44.

9. Donley N, Jaruga P, Coskun E, Dizdaroglu M, McCullough AK, Lloyd RS Small molecule inhibitors of 8-oxoguanine DNA glycosylase-1 (OGG1). ACS Chem Biol. 2015;10:2334-43.

10. Tahara Y, Auld D, Ji D, Beharry AA, Kietrys AM, Wilson DL, Jimenez M, King D, Nguyen Z, Kool ET. Potent and selective inhibitors of 8-oxoguanine DNA glycosylase. J Am Chem Soc. 2018;140:2105-14.

11. Alekseev S, Ayadi M, Brino L, Egly J-M, Larsen AK, Coin F. A small molecule screen identifies an inhibitor of DNA repair inducing the degradation of $\mathrm{TFIIH}$ and the chemosensitization of tumor cells to platinum. Chem Biol. 2014;21:398-407.

\section{Publisher's Note}

Springer Nature remains neutral with regard to jurisdictional claims in published maps and institutional affiliations.

Ready to submit your research? Choose BMC and benefit from:

- fast, convenient online submission

- thorough peer review by experienced researchers in your field

- rapid publication on acceptance

- support for research data, including large and complex data types

- gold Open Access which fosters wider collaboration and increased citations

- maximum visibility for your research: over $100 \mathrm{M}$ website views per year

At BMC, research is always in progress.

Learn more biomedcentral.com/submissions 